\title{
Comparison of Nuclear Energy of Bangladesh with India \& Pakistan.
}

\author{
Rafia Akhter, Md. Ishtiaque Aziz Zahed \\ EEE, Bangladesh University of Engineering \& Technology/ Bangladesh
}

\begin{abstract}
Nuclear power is a unique source of energy for power production. Uninterrupted electric supply is essentially required for the smooth running of the modern society. Bangladesh is not alone in finding difficulties to fulfill its domestic energy demand; many countries around the world are facing similar problems. South Asian countries face on average a shortage of $15 \%$ to $30 \%$ of electricity with respect to peak load demand. South Asia has huge untapped hydropower potential. Only Pakistan, Bhutan and Nepal have technoeconomically feasible hydropower potentials. There is a general neglect of electricity generation from renewable sources in South Asia, although huge potential exist for wind power, especially in coastal areas of India and Pakistan. However, India is taking the lead in developing renewable energy in the region. In this paper, Nuclear energy of Bangladesh is compared with other developing countries of South Asia like India and Pakistan.
\end{abstract}

Keywords: Nuclear power, generation, Asia, $M W$

\section{INTRODUCTION}

South Asia is an under-developed and energy resources deficient region that housed 1.5 billion people at present, which makes one-fourth of the world population. The region contains the highest number of people without access to electricity (612 Million)[1]. Per capita energy consumption in South Asia has been less than $3 \%$ of the per capita energy consumption in the United States. Key statistics of overall energy Availability and consumption in the countries of the region is given at Table-I.

Table-I Comparison of Key Energy Indicators over time Across South Asian Countries

\begin{tabular}{|c|c|c|c|c|c|c|c|c|c|c|c|c|c|c|}
\hline \multirow[b]{2}{*}{ Country } & \multicolumn{2}{|c|}{$\begin{array}{c}\text { Population } \\
\text { (Aillion) }\end{array}$} & \multicolumn{2}{|c|}{$\begin{array}{l}\text { Energy Production } \\
\text { (Million Tons of Oil } \\
\text { Equivalent) }\end{array}$} & \multicolumn{2}{|c|}{$\begin{array}{c}\text { Energy Use } \\
\text { (Million Tons of } \\
\text { Oil Equi.) }\end{array}$} & \multicolumn{2}{|c|}{$\begin{array}{l}\text { Fossil Fuels } \\
\text { Percent of Total } \\
\text { Use ( } \% \text { ) }\end{array}$} & \multicolumn{2}{|c|}{$\begin{array}{l}\text { GDP per unit of } \\
\text { Energy Use } 2005 \\
\text { PPPS Kg of oil Equi }\end{array}$} & \multicolumn{2}{|c|}{$\begin{array}{l}\text { Net Energy } \\
\text { Imports of } \\
\text { Energy Use (\%) }\end{array}$} & \multicolumn{2}{|c|}{$\begin{array}{c}\text { Energy Intensity } \\
\text { BTU per Year } \\
2005 \text { USS }\end{array}$} \\
\hline & 1990 & 2008 & 1990 & 2008 & 1990 & 2008 & 1990 & 2008 & 1990 & 2008 & 1990 & 2008 & 1990 & 2008 \\
\hline India & 858.2 & 1140.6 & 291.8 & 468.3 & 318.9 & 621.0 & 55.7 & 71. & 3.3 & 5.1 & 0 & 25 & 22,337 & 18,825 \\
\hline Pakistan & 118.8 & 178.5 & 34.3 & 63.3 & 43.0 & 82.8 & 52.8 & 61.8 & 4.2 & 4.7 & 20 & 24 & 20,230 & 19,852 \\
\hline Bangladesh & 112.2 & 151.3 & 10.8 & 23.4 & 12.7 & 27.9 & 45.5 & 68.4 & 6.2 & 7.1 & 16 & 16 & 9,155 & 12,577 \\
\hline Nepal & 18.9 & 28.2 & 5.5 & 8.7 & 5.8 & 9.8 & 5.1 & 10.9 & 2.3 & 3 & 5 & 11 & 4,164 & 8,157 \\
\hline iL Lanka & 17.4 & 21.1 & 4.2 & 5.1 & 5.5 & 8.9 & 24.1 & 43.4 & 6.3 & 9.5 & 24 & 43 & 8,730 & 7,241 \\
\hline
\end{tabular}

Nuclear power is desirable in Bangladesh, due to its underdeveloped and mismanaged energy infrastructure that has inhibited Bangladeshi growth (See: Electricity sector in Bangladesh). With a derated capacity of around 5500 Megawatt (MW) on an installed rating of over $6000 \mathrm{MW}$, only around 4000 is actually available. With a maximum generation of $4500 \mathrm{MW}$ in mid-2010 to $4700 \mathrm{MW}$ in late 2010 , the peak is anywhere from $5700 \mathrm{MW}$ to $6000 \mathrm{MW}$ and only about $40 \%$ to $48 \%$ of the total population have access to electricity. The per capita consumption of $218-230 \mathrm{kWh}$ and the availability is the lower among any developing country in the world.

As of 2012, nuclear power in Pakistan is provided by 3 licensed-commercial nuclear power plants. Pakistan is the first Muslim country in the world to construct and operate civil nuclear power plants.[2] The Pakistan Atomic Energy Commission (PAEC), the scientific and nuclear governmental agency, is solely responsible for operating these power plants. As of 2012, the electricity generated by commercial nuclear power plants constitutes roughly $\sim 3.6 \%$ of electricity generated in Pakistan, compared to $\sim 62 \%$ from fossil fuel, $\sim 33 \%$ from hydroelectric power and $\sim 0.3 \%$ from Coal electricity.[3] Pakistan is one of the four nuclear armed states (along with India, Israel, and North Korea) that is not a party to the Nuclear Non-Proliferation Treaty but is a member in good standing of the International Atomic Energy Agency.[4]

In India, there are presently 19 nuclear power reactors in operation with a capacity of $4560 \mathrm{MW}$. The 20th reactor, Kaiga-4 (220-MW), currently under the process of fuel loading, is expected to go in operation by December 2010, thus raising the nuclear power installed capacity to 4780 MW. Kaiga-4 brings yet another distinction to the country, elevating it to 6th rank in the world after US, France, Japan, Russian federation and Republic of Korea to have 20 or more nuclear power reactors in operation currently. In addition, three nuclear 
power reactors with a capacity of $2500 \mathrm{MW}$ are at an advanced stage of construction and four reactors each of $700 \mathrm{MW}$, two each at Kakrapar in Gujrat and Rawatbhata in Rajasthan, respectively, have also been launched for construction during this year. With the completion of the reactors under construction, the nuclear power capacity in the country will reach $7280 \mathrm{MW}$ by 2012 and $10080 \mathrm{MW}$ by 2017.[5]

\section{Background And History}

For Bangladesh, which is a historically agrarian country, the agricultural sector has shrunk from over $30 \%$ in the 1980 s to under $20 \%$ a decade into the millennium. On the other hand, industry is growing from under $20 \%$ in the 1980 s to over $30 \%$ currently. With highly industry national economy, the generation of electricity will be linearly related to the national GDP. With lesser agriculture and more industry, not only more emissions will be given off to the atmosphere but lack of trees and plants will hinder any chance of carbon sequestration. [3]

Pakistan, first commercial nuclear power reactor, [6] Known as Karachi Nuclear Power Plant (KANUPP) a small 137 MWe CANDU reactor, was developed. Then In 1969, France contracted with PAEC to provide plutonium and nuclear reprocessing plants in Pakistan. The work on projects did not start until 1972. In 1974, PARR-II Reactor was commissioned. In 1989, People's Republic of China signed an agreement with Pakistan to provide 300 MWe CHASNUPP-I power plant under the IAEA safeguards. In 1990, both France and Soviet Union considered the Pakistan's request to provide the commercial nuclear power plants under the IAEA safeguards. [7] By the 2000, China had expanded its contract with PAEC and is currently assisting in construction of III, and IV power plants. According to PAEC, the goal is to produce $8800 \mathrm{MW}$ electricity by the 2030. The PAEC are currently planning to lead the construction of KANUPP-II nuclear power plant - a $1000 \mathrm{MWe}$ power plant — and the KANUPP-III - 1000 MWe. While the commercial plants will be indigenously built, the preliminary work is put on hold as of 2009. In 2010, the Nuclear Power Fuel Complex (PNPFC) - a nuclear reprocessing power plant - was commissioned. PAEC led the construction, designing, and maintenance of the facility, while China and IAEA provided funds to the facility. [8]

India's first research nuclear reactor and its first nuclear power plant were built with assistance from Canada. The $40 \mathrm{MW}$ research reactor agreements were signed in 1956, and CIRUS achieved first criticality in 1960. This reactor was supplied to India on the assurance that it would not be used for military purposes, but without effective safeguards against such use. [9] The agreement for India's first nuclear power plant at Rajasthan, RAPP-1, was signed in 1963, and followed by RAPP-2 in 1966. These reactors contained rigid safeguards to ensure they would not be used for a military programme. The $200 \mathrm{MWe}$ RAPP-1 reactors were based on the CANDU reactor at Douglas Point and began operation in 1972. Due to technical problems the reactor had to be downrated from $200 \mathrm{MW}$ to $100 \mathrm{MW}$. The technical and design information were given free of charge by AECL to India. The United States and Canada terminated their assistance after the detonation of India's first nuclear explosion in 1974; RAPP-2 was not completed.

\section{Generation Capacity and Load Shedding}

South Asian countries face on average a shortage of $15 \%$ to $30 \%$ of electricity with respect to peak load demand (Table 2). South Asia has huge untapped hydropower potential. Only Pakistan, Bhutan and Nepal have techno-economically feasible hydropower potentials of $50 \mathrm{GW}, 23.7 \mathrm{GW}$ and $42 \mathrm{GW}$ respectively. Bangladesh and Sri Lanka have exhausted their hydropower source to a large extent. Electricity demand due to rapid economic growth and depletion of domestic gas reservoirs is the key to energy crisis in Bangladesh. Pakistan has enormous hydel generation potential and can export surplus electricity to these countries by tapping its huge potential Regional electricity trade may be an option to mitigate the shortfalls in South Asia. Trade of electricity on small scale is already taking place in the region. For example, India is importing around 1,200 MW of electricity from Bhutan. Pakistan is importing electricity from Iran.

Table-II Comparison of Electricity profiles of South Asian Countries ( 1990 to 2008)

\begin{tabular}{|l|c|c|c|c|c|c|c|c|}
\hline \multirow{3}{*}{ Country } & \multicolumn{2}{|c|}{$\begin{array}{c}\text { Electricity } \\
\text { Installed Capacity } \\
\text { (GW) }\end{array}$} & \multicolumn{2}{c|}{$\begin{array}{c}\text { Electricity } \\
\text { Generation } \\
\text { (000, GIVh) }\end{array}$} & \multicolumn{2}{c|}{$\begin{array}{c}\text { Distribution } \\
\text { Losses } \\
\text { (Percent) }\end{array}$} & \multicolumn{2}{|c|}{$\begin{array}{c}\text { Per capita } \\
\text { Consumption } \\
\text { (KWh) }\end{array}$} \\
\cline { 2 - 10 } & $\mathbf{1 9 9 0}$ & $\mathbf{2 0 0 8}$ & $\mathbf{1 9 9 0}$ & $\mathbf{2 0 0 8}$ & $\mathbf{1 9 9 0}$ & $\mathbf{2 0 0 8}$ & $\mathbf{1 9 9 0}$ & $\mathbf{2 0 0 8}$ \\
\hline India & $\mathbf{7 4 . 6 9}$ & 177.38 & 275.49 & 785.53 & 20.52 & 24.66 & 276 & 566 \\
\hline Pakistan & 7.74 & 19.77 & 36.34 & 87.74 & 21.48 & 21.87 & 277 & 436 \\
\hline Bangladesh & 2.52 & 5.45 & 7.62 & 32.93 & 34.08 & 13.17 & 44 & 149 \\
\hline Nepal & 0.27 & 0.72 & 0.90 & 3.05 & 18.40 & 19.56 & 35 & 89 \\
\hline Sri Lanka & 1.29 & 2.64 & 3.12 & 8.89 & 16.86 & 11.33 & 149 & 414 \\
\hline
\end{tabular}

There is a general neglect of electricity generation from renewable sources in South Asia, although huge potential exist for wind power, especially in coastal areas of India and Pakistan. However, India is taking the lead in developing renewable energy in the region. The installed capacity of wind power in India of 2 GW (out of $43 \mathrm{GW}$ gross potential) is the 5th largest wind power installed capacity in the world. Renewable capacity 
is generally add to the off-grid systems based on small hydro power or solar/wind/biomass power plants in few countries.

\section{Nuclear Power Generation}

Nuclear power have high capital cost for building the plant and relatively low fuel cost. Currently, two South Asian economies viz. India and Pakistan are generating nuclear electric power while Bangladesh and Sri Lanka may join the group in future. Bangladesh Atomic Energy Commission (BAEC) for instance, has set a target of raising the share of nuclear electricity in total generation up to $10 \%$ by 2021 . The historical nuclear electricity generation in India and Pakistan is shown in Figure 1.
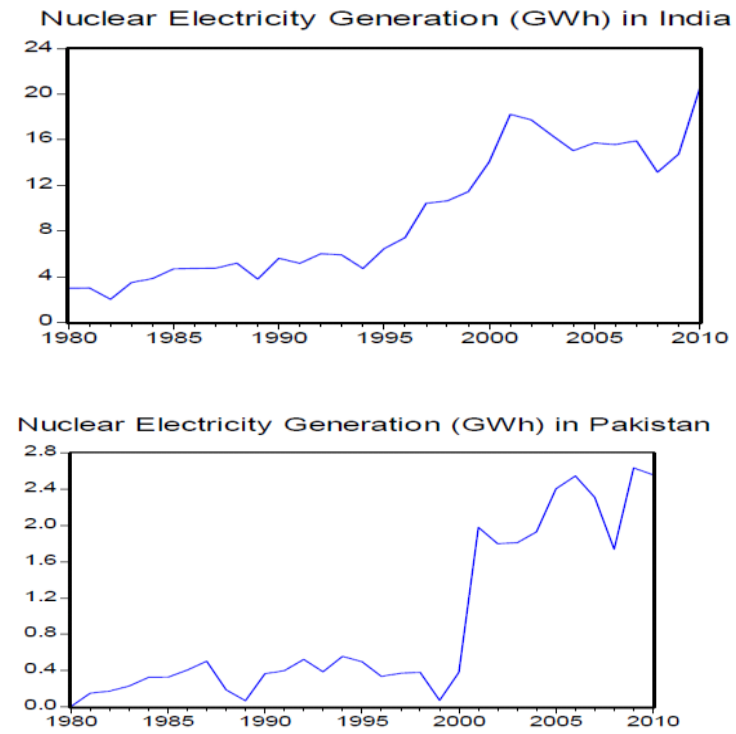

Fig. 1 Nuclear Electricity Generation in India and Pakistan During the period 1980-2010 Where in

Bangladesh,[10], Nucl;ear Energy statistics are is nil.

\section{Current Plans Up To 2020 / Perspective Energy Plan of Present Government}

Bangladesh first considered building a nuclear power plant in 1961. Since then, several feasibility studies have been carried out, affirming the feasibility of the project. In 1963 the Ruppur site was selected. More recently, in 2001 Bangladesh adopted a national Nuclear Power Action Plan. On 24 June 2007, Bangladesh's government announced plans to build a nuclear power plant to meet electricity shortages. In May 2010, Bangladesh signed a civilian nuclear agreement with the Russian Federation. Bangladesh also has framework agreement for peaceful nuclear energy applications with the US, France and China. Although the Ministry of Science and ICT, the Ministry of Energy and Mineral Resources and Bangladesh Power Development Board (BPDB) are working on the electric grid system integration, the demographics and circumstances present do raise the question if indeed Bangladesh can produce energy from nuclear sources. ${ }^{[1]}$

In February 2011, Bangladesh reached an agreement with Russia to build the 2,000 megawatt (MW) Ruppur Nuclear Power Plant with two reactors, each of which will generate 1,200 MW of power. The nuclear power plant will be built at Ruppur, on the banks of the Padma River, in the Ishwardi subdistrict of Pabna, in the northwest of the country. The RNPP is estimated to cost up to US\$2 billion, and start operating by 2021. [12] The inter-governmental agreement (IGA) was officially signed on 2 November 2011.[14]On 29th May, 2013 Bangladesh's prime minister declared that a second nuclear power plant will be constructed in an inland river island in southern region of the country. The Perspective Plan of the Planning Commission of the government of Bangladesh for the period 2010 - 2021 has recommended an energy mix to achieve the generation of 20,000 MW by 2021. Targets of electricity production by 2013 and 2015 are 7,000 MW and $8000 \mathrm{MW}$, respectively. According to the Perspective Plan, the energy mix for power generation is as follows.[11] Table -III: Energy mix of the Perspective Plan 2010 - 2025 for power generation.

\begin{tabular}{|c|c|c|c|}
\hline \multirow{2}{*}{ Energy Sources } & \multirow{2}{*}{\multicolumn{3}{|c|}{\begin{tabular}{|l|l|}
\multicolumn{2}{|c|}{ Target Period } \\
Current $2021 \mid 2030$
\end{tabular}}} \\
\hline & & & \\
\hline Nuc & $0 \%$ & $10 \%$ & $19 \%$ \\
\hline Renewable & $0 \%$ & $3 \%$ & $6 \%$ \\
\hline
\end{tabular}


As of today, In Pakistan, only 3 three commercial nuclear power plants are currently operating. The list provided the information about current and future commercial nuclear power plants.[11]In Table-IV, current and future commercial nuclear power plants of Pakistan is given.

Table-IV future commercial nuclear power plants of Pakistan

\begin{tabular}{|c|c|c|c|c|c|c|c|}
\hline $\begin{array}{c}\text { Nuclear power } \\
\text { reactors }\end{array}$ & Type & Location & $\begin{array}{c}\text { Net } \\
\text { capacity }\end{array}$ & $\begin{array}{c}\text { Gross } \\
\text { capacity }\end{array}$ & Construction start & \begin{tabular}{|c|}
$\begin{array}{c}\text { Connected to } \\
\text { grid }\end{array}$ \\
\end{tabular} & $\begin{array}{c}\text { Commercial } \\
\text { operation }\end{array}$ \\
\hline CHASNUPP-III & PWR & $\begin{array}{l}\text { Chasma, } \\
\text { Punjab } \\
\text { Province }\end{array}$ & $340 \mathrm{MWe}$ & $330 \mathrm{MWe}$ & 28 April 2009 & 2016 & $\mathrm{~N} / \mathrm{A}$ \\
\hline CHASNUPP-IV & PWR & $\begin{array}{l}\text { Chasma, } \\
\text { Punjab } \\
\text { Province }\end{array}$ & $340 \mathrm{MWe}$ & $330 \mathrm{MWe}$ & 2011 & 2017 & $\mathrm{~N} / \mathrm{A}$ \\
\hline CHASNUPP-V & PWR & $\begin{array}{l}\text { Chasma, } \\
\text { Punjab } \\
\text { Province }\end{array}$ & $\begin{array}{l}1000 \\
\mathrm{MWe}\end{array}$ & $\begin{array}{l}1000 \\
\mathrm{MWe}\end{array}$ & 2014 & 2020 & $\mathrm{~N} / \mathrm{A}$ \\
\hline
\end{tabular}

In Table-V, Power reactors planned or firmly proposed for India, is given.

Table-V Power reactors planned or firmly proposed for India

\begin{tabular}{|c|c|c|c|c|c|c|}
\hline Reactor & State & Type & $\begin{array}{l}\text { MWe gross, } \\
\text { each }\end{array}$ & $\begin{array}{l}\text { Project } \\
\text { control }\end{array}$ & $\begin{array}{l}\text { Start } \\
\text { construction }\end{array}$ & $\begin{array}{l}\text { Start } \\
\text { operation }\end{array}$ \\
\hline Kudankulam 3 & Tamil Nadu & PWR - AES 92 & 1050 & NPCIL & 2014 & 2019 \\
\hline Kudankulam 4 & Tamil Nadu & PWR - AES 92 & 1050 & NPCIL & 2014 & 2020 \\
\hline Jaitapur 1\&2 & Ratnagiri, Maharashtra & PWR - EPR x 2 & 1700 & NPCIL & 2013 & $2018-19$ \\
\hline Kudankulam 5\&6 & Tamil Nadu & $\begin{array}{c}\text { PWR - AES } 92 \text { or } \\
\text { AES-2006 }\end{array}$ & $1050-1200$ & NPCIL & 2014 & $2019-21$ \\
\hline $\begin{array}{c}\text { Gorakhpur/ } \\
\text { Kumbariya } 1 \& 2 \\
\end{array}$ & Haryana (Fatehabad district) & PHWR $\times 2$ & 700 & NPCIL & by 2017 & $2018-19$ \\
\hline Chutka 1\&2 & Madhya Pradesh & PHWR $\times 2$ & 700 & NPCIL & $6 \& 12 / 2015$ & 2020,21 \\
\hline Kalpakkam 2\&3 & Tamil Nadu & FBR $\times 2$ & 500 & Bhavini & 2014 & 2019-20 \\
\hline Jaitapur 3\&4 & Ratnagiri, Maharashtra & PWR - EPR & 1700 & NPCIL & 2016 & $2021-22$ \\
\hline Mithi Virdi 1-2 & $\begin{array}{l}\text { Bhavnagar, Gujarat (Saurashtra } \\
\text { region) }\end{array}$ & $2 \times \mathrm{AP} 1000$ & 1250 & NPCIL & $2014 ?$ & $2019-20$ \\
\hline Mithi Virdi 3-4 & Bhavnagar, Gujarat & $2 \times \mathrm{AP} 1000$ & 1250 & NPCIL & 2015 & $2020-21$ \\
\hline Kovvada 1-2 & Srikakulam, Andhra Pradesh & $2 \times$ ESBWR & $\begin{array}{c}1350-1550 \\
(1400 ?)\end{array}$ & NPCIL & \begin{tabular}{|l} 
site works, \\
2014 \\
\end{tabular} & 2019-20 \\
\hline Haripur 1-2 & $\begin{array}{l}\text { West Bengal (but likely } \\
\text { relocated, maybe to Orissa) }\end{array}$ & $\begin{array}{c}\text { PWR x } 4 \text { VVER- } \\
1200\end{array}$ & 1200 & & 2014 & $2019-21$ \\
\hline Haripur 3-4 & West Bengal & $\begin{array}{c}\text { PWR x } 4 \\
\text { VVER1200 }\end{array}$ & 1200 & & 2017 & $2022-23$ \\
\hline Mithi Virdi 5-6 & Bhavnagar, Gujarat & $\mathrm{AP} 1000 \times 2$ & $1250 \times 2$ & & $2023-24$ & \\
\hline Subtotal proposed & & approx 39 & $\begin{array}{l}\text { 45,000 MWe } \\
\text { approx }\end{array}$ & & & \\
\hline
\end{tabular}

\section{CONCLUSION}

Asia is the main region in the world where electricity generating capacity and specifically nuclear power is growing significantly. In East and South Asia there are 119 operable nuclear power reactors, 49 under construction and firm plans to build a further 100. Many more are proposed. The study concludes the summary of the three countries in Table -VI \&. Though among India, Pakistan and Bangladesh, India and Pakistan have already got some installed capacity but including Bangladesh both of them need more nuclear sectors in the region and increased of installation is required. 
In Table VI no. of reactors and capacity, megawatts, is compared among the three countries.

Table:VI (Nuclear Power in Asia, and Involvement with the Nuclear Fuel Cycle)[13]

\begin{tabular}{|c|c|c|c|c|c|}
\hline & \begin{tabular}{|l} 
Power Reactors \\
operable or in \\
Operation
\end{tabular} & $\begin{array}{l}\text { Power Reactors } \\
\text { Under Construction }\end{array}$ & \begin{tabular}{||l} 
Power \\
Reactors \\
Planned
\end{tabular} & $\begin{array}{l}\text { Research } \\
\text { Reactors }\end{array}$ & $\begin{array}{l}\text { Other } \\
\text { Stages of } \\
\text { the Fuel } \\
\text { Cycle }\end{array}$ \\
\hline Bangladesh & & & 2 & 1 & \\
\hline India & 20 & 7 & 18 & 5 & $\begin{array}{l}\text { UM, FF, } \\
\text { R, WM }\end{array}$ \\
\hline Pakistan & 3 & 2 & 0 & 1 & $\mathrm{UM}, \mathrm{E}, \mathrm{FF}$ \\
\hline
\end{tabular}

Table: VII (no. of reactors and capacity, megawatts, MW) [14]

\begin{tabular}{|c|c|c|c|c|c|c|c|c|c|}
\hline & \multicolumn{2}{|l|}{ Operator } & \multicolumn{2}{|l|}{ Construction } & \multicolumn{2}{|l|}{ Planned } & \multicolumn{2}{|l|}{ Proposed } & \multirow{2}{*}{$\begin{array}{l}\text { Uranium } \\
\text { Demand } \\
\text { 2008(tonnes) } \\
\end{array}$} \\
\hline & No & MW & No & MW & No & MW & No & MW & \\
\hline India & 17 & 8,857 & 5 & 4,540 & 30 & 32,000 & 86 & 68,000 & 1,396 \\
\hline Pakistan & 2 & 400 & 1 & 300 & 2 & 600 & 2 & 2,000 & 65 \\
\hline
\end{tabular}

\section{REFERENCES}

[1] Sunny, Sanwar, “Green Buildings, Clean Transport and the Low Carbon Economy. Germany”, LAP Publishers. pp. $145-147$. ISBN 978-3-8465-9333-2.

[2] Zulfikar, Saman (Monday, April 23, 2012), "Pak-China energy cooperation", Pakistan Observer.

[3] Syed Yousaf, Raza (July 31, 2012), "Current Picture of Electrical Energy In Pakistan",Pakistan Atomic Energy Commission (in English). Directorate-General for Nuclear Power Generation. Retrieved 28 November 2012.

[4] Associate Press of Pakistan (APP)), "IAEA declares nuclear energy programme safe", Dawn Newspapers, 25 th April, 2011. Retrieved 17 April 2012.

[5] UN Press Release, "IAEA Publications: Pakistan Overview", IAEA, P.O. Box 100, Wagramer Strasse 5, A-1400 Vienna, Austria. IAEA Membership states. Retrieved 17 April 2012.

[6] From Wikipedia, the free encyclopedia.

[7] Siddiqui, Dr. Zia; Dr. Iqbal Hussain Qureshi, "Nuclear power in Pakistan",The Nucleus (Nilore, Islamabad: The Nucleus PINSTECH publication) 42 (1-2): 63-66. ISSN 0029-5698. Retrieved 2011.

[8] http://www.ccnr.org/exports_3.html

[9] Fuhrmann, Matthew ," Atomic Assistance: How "Atoms for Peace", Texas: Cornell University Press. pp. 93-95. ISBN 9780801478116.

[10] Source: Energy Information Administration, Official Energy Statistics from the US Government, FORUM: A monthly publication of 'œThe Daily Star'?], Volume 3, Issue 1, January 2010, Official web site of Bangladesh Petroleum Corporation.

[11] Source: The Perspective Plan for Bangladesh 2010-2021.

[12] Chowdhury, Syed Tashfin, "Bangladesh signs up for nuclear power", Asia Times. Retrieved 16 August 2011.

[13] Chowdhury, Syed Tashfin,"Bangladesh, Russia sign nuclear plant deal",Asia Times. Retrieved 7 November 2011.

[14] http://www.world-nuclear.org/info/Country Profiles/Others/Asia-s-Nuclear-Energy-Growth/Source: World Nuclear Association, January 2008 